\begin{tabular}{l|l} 
& $\begin{array}{l}\text { Eastern } \\
\text { European } \\
\text { Countryside }\end{array}$ \\
\hline $20^{\prime} 2014$
\end{tabular}

\author{
Tamara Lukić1, Ivana Penjišević, Bojan Đerčan, Branislav \\ Đurđev, Milka Bubalo Živković, Tanja Armenski
}

\title{
Politics in the Balkan countryside: case study in Serbia
}

\begin{abstract}
Thanks to the field observations conducted on the territory of central Serbia, it was noticed that people in rural environment, beside the optional conversations about weather conditions, most often talk about the politics. The aim of this work was to find out how many people who live in the countryside have the contact with the politics. Hypothesis were made within the communication with several examinees, but they were verified by the poll in which more than 100 persons took part. Data were analyzed by descriptive statistics, using T-test, one-factor analysis of ANOVA variance, and also they were checked by Post-hoc Tukey test. The work task was to find out if gender, age, as well as, professional and regional differences exist in relation to the countryside inhabitants considerations about certain political issues they have been talking about. The importance of this work is to discover whether the distance from urban environments and, life in nature can make a man less interested in and indifferent to the politics.
\end{abstract}

Keywords: Balkan countryside, politics, Serbia

\footnotetext{
1 snstamara@yahoo.com
} 


\section{Introduction}

Old Greek philosopher, Aristotle, gave a definition of the essence of man, calling him a „zōon politikon” or a man as a social, political being. The territory of the Balkan Peninsula, shared; among others, between Serbia and Greece, had glorious and turbulent history. Numerous wars and other historical events forced the inhabitants, usually in rural territory, to be informed even in the time when the information was not exchanged at the light speed. Nowadays, in the time of modern technologies, which ensure undisturbed circulation of information in different ways, the inhabitant of rural environment theoretically may be well informed about everything, even about the politics, so he can have a formed opinion. The aim of this work was to find out how much is the man from here, a dweller of the rural settlements in Serbia, „zōon politikon“. It was understood as his knowledge about politics in general, having the opinion, attitude, and perception power about life changes in the countryside under influence of political changes, as well as, the general importance of the politics in his life.

\section{Methods}

The facts shown in this work are the result of consultation with literature and own investigation. The opinion about politics in the countryside was shown on the basis of the poll results. The examinees represented the random sample of inhabitants who live in the countryside. Some authors believe that the estimations from applied statistic methods will be good only if the sample contains minimum 51 units (Bagozzi 1981). Taking the above statement into consideration, it may be concluded that the sample used in this investigation $(n=105)$ was representative. The poll of ten questions was correctly filled in by 105 examinees or $80.8 \%$ of the interviewed, mostly males (51.4\%). More than a half (50.5\%) lived on the hilly terrain or in the mountain. Three quarters of the examinees (76\%) were not engaged in the politics. (Table 1) Almost the quarter of examinees $(24.8 \%)$ represented the age group from 30 to 39 years, and almost one third were employed (32.4\%). Hypothesis were measured on a five-point Likert type scale ranging from 1 (strongly disagree) to 5 (strongly agree). The interviewing was conducted during August 2013. Data were analyzed by descriptive statistics and using T-test, one-factor analysis of ANOVA 
variance and Post-hoc Tukey HSD test. T-test was made with independent samples and compared by arithmetic mean of two groups. As it was not possible to assume the result of comparison, 2 tailed test was used. The results of T-test discovered significant statistic differences between average mean of the examinees gender, political engagement and the origin of the examinees according to the altitude they have settled at, at the importance level $\mathrm{p}<0.01(\mathrm{t} \geq 2.57)$ (Pearson and Hartley 1966).

Table 1. Sample of respondents

\begin{tabular}{cc}
\hline Number of responses & 105 \\
\hline Gender & \\
Male & 51.4 \\
Female & 48.6 \\
Membership of the political option & \\
Correct & 23.8 \\
Incorrect & 76.2 \\
Place of living & \\
River valley, plain, flat terrain & 49.5 \\
Mountain, hilly terrain & 50.5 \\
Age & \\
20-29 & 11.4 \\
30-39 & 24.8 \\
$40-49$ & 21.9 \\
50-59 & 19.0 \\
$60+$ & 22.9 \\
Activity & \\
Farmer & 31.4 \\
Farmer with employed & 11.4 \\
Employed & 32.4 \\
Pensioner & 9.5 \\
Unemployed & 9.5 \\
Other & 5.7 \\
\hline &
\end{tabular}

Source: Survey research. 
In order to establish the existence of statistically important relations between dependant variables (attitudes about politics) and independent variables (socially-demographic characteristics of the examinees, which; in that case, were age and activity) one-factory analysis of ANOVA variance was applied. In both cases, significant statistical differences in evaluation of hypothesis on the important level $\mathrm{p}<0.01 ; \mathrm{F} \geq 3.47$ were investigated. Hypotheses, where there were differences found, were tested by the posthoc Tukey HSD test. In that way, the age groups and activities of the examinees that influenced existing difference in one-factor analysis were established.

\section{Study area}

Municipalities of Serbia; where the poll was conducted, were chosen according to the criteria that included settlements at higher and lower altitudes. Therefore, the examinees live in the municipalities of Raška (settlements: Rvati, Beoci, Brvenik, Biljanovac, Korlaće, Jošanička Banja, Semeteš, Gradac, Draganiće, Varevo i Gnjilica), Kraljevo (settlements: Konarevo, Progorelica, Samaila, Adrani, Mlanča, Studenica i Ušće na Ibru), Vrnjačka Banja (settlements: Vrnjci, Ruđinci, Vukušica, Otroci, Dragosinjci, Stanišinci), Vranjska Banja (settlement: Korbevac), Kruševac (settlement: Kupci), Novi Pazar (settlement: Deževa), Brus (settlement: Blaževo) (Figure I).

\section{Results and Discussions}

The values of arithmetic mean, and average evaluation of hypothesis were in range from 2.61 (the lowest value) to 4.51 (the highest value). The hypothesis 'The politicians are present the most in a countryside during the election campaign' had the highest average grade. According to the value of standard deviation $(\sigma=0.76)$ of this hypothesis, it may be concluded that it is the only hypothesis on which the examinees agreed $(\sigma<1.00)$ (Figure II). The other hypotheses on which the examinees mostly agreed, where the values of standard deviations were slightly above the limited value 1 , were: 'The best policy is the one that 'leaves the most in the peasants pocket' $(\sigma=1.02)$ and 'If I were the politician, I would exactly know what should be changed' $(\sigma=1.06)$. With a half of ten put hypothesis the examinees 
Figure 1. Geographic position of municipalities where the settlements in which the examinees live are located

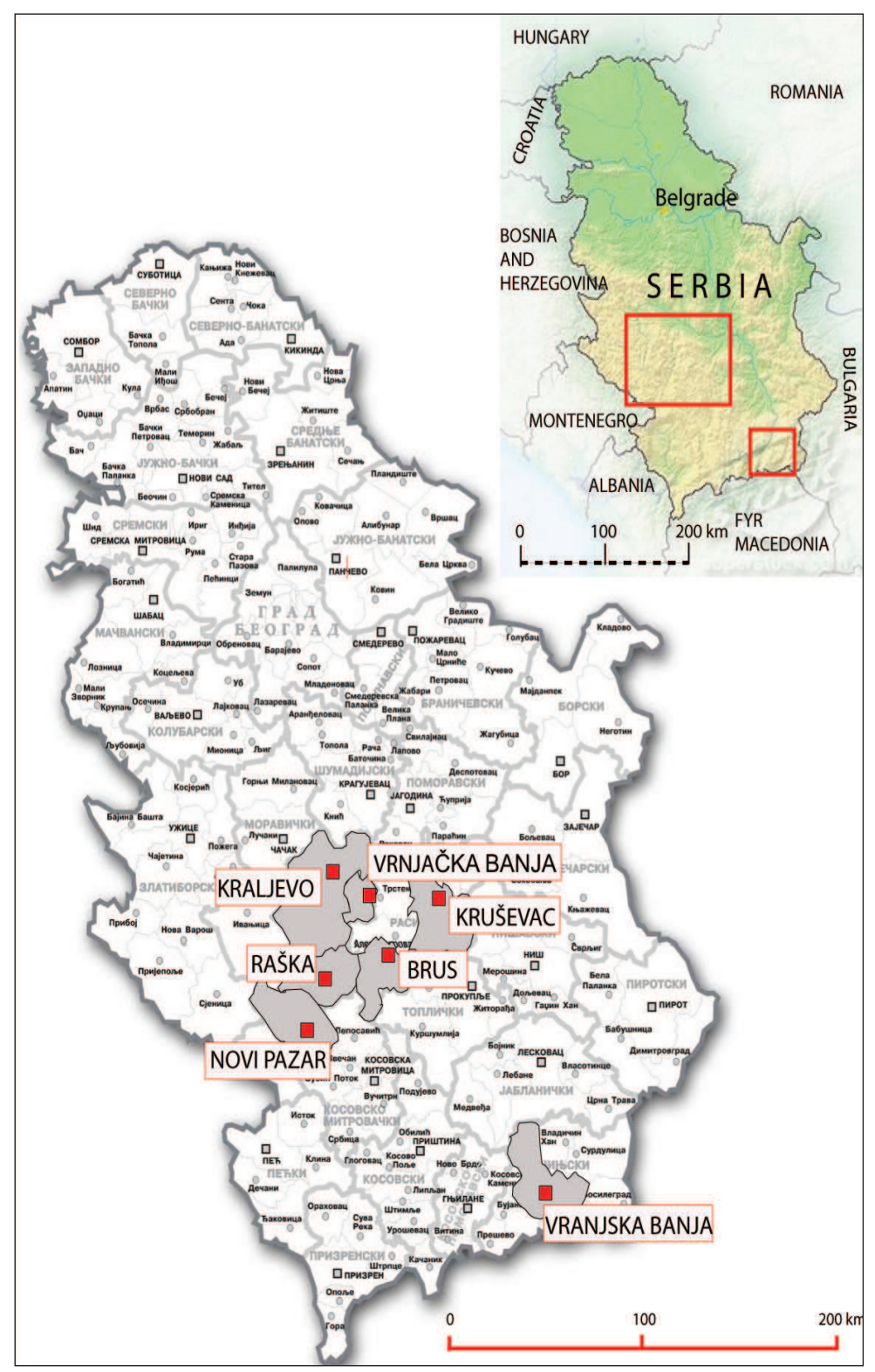

Source: own research. 
generally agreed (average value was from 3.56 to 4.51 ) while the second half were indecisive (average value was from 2.61 to 3.36). Hereinafter, there is the survey of reactions of particular groups of the examinees concerning certain hypothesis provided.

Hypothesis 1: "I regularly follow 'the political life' in Serbia"

Some people are more politically interested than others, but political scientists do not know how stable these differences are and why they occur (Prior 2010). The average value of this hypothesis (3.36) shows that some examinees regularly follow 'the political life' in Serbia while others do not do that $(\sigma=1.38)$. T-test showed significant differences between arithmetic means of male and female examinees. Actually, men agreed that they regularly follow 'political life in Serbia, while women were indecisive about this question. Statistically, there were significant differences between arithmetic means of the examinees who are politically engaged and those who are not. Politically engaged ones naturally agreed $(M=4.44$ and $\sigma=1.00)$ that they regularly follow 'the political life' in Serbia. Those who are not politically engaged were not able to say with certainty that they follow it regularly. On the basis of the value of their standard deviation $(\sigma=1.31)$, the investigation was continued by applying one-factor analysis of ANOVA variance. At the importance level $\mathrm{p}<0.01 ; \mathrm{F} \geq 3.47$, differences between acceptance of this hypothesis by the examinees of different age groups were not found. Hajdar and Schlapbach (2009) also found out that there were no differences in the age cohorts concerning the level of interests in the politics. However, the differences were established between the examinees of different activities. Post hoc Tukey test was helpful for identifying isolated examinees groups. According to this test, the biggest differences in opinion were between employed people and pensioners, employed people and those within the category of 'others'. It is obvious that employed people are more interested in the politics in relation to the mentioned categories of inhabitants (Table 8).

Hypothesis 2: 'I know who the Minister of Agriculture is'

At the time of polling, the Government of the Republic of Serbia was under the process of reconstruction. This question was asked as a kind of control question in relation to the first one. Only those who really follow 'the political life' in Serbia could confirm to know who the minister of agriculture is. According to the average value (3.70) the examinees in rural settlements of Serbia agreed to know who the minister of agriculture was. 


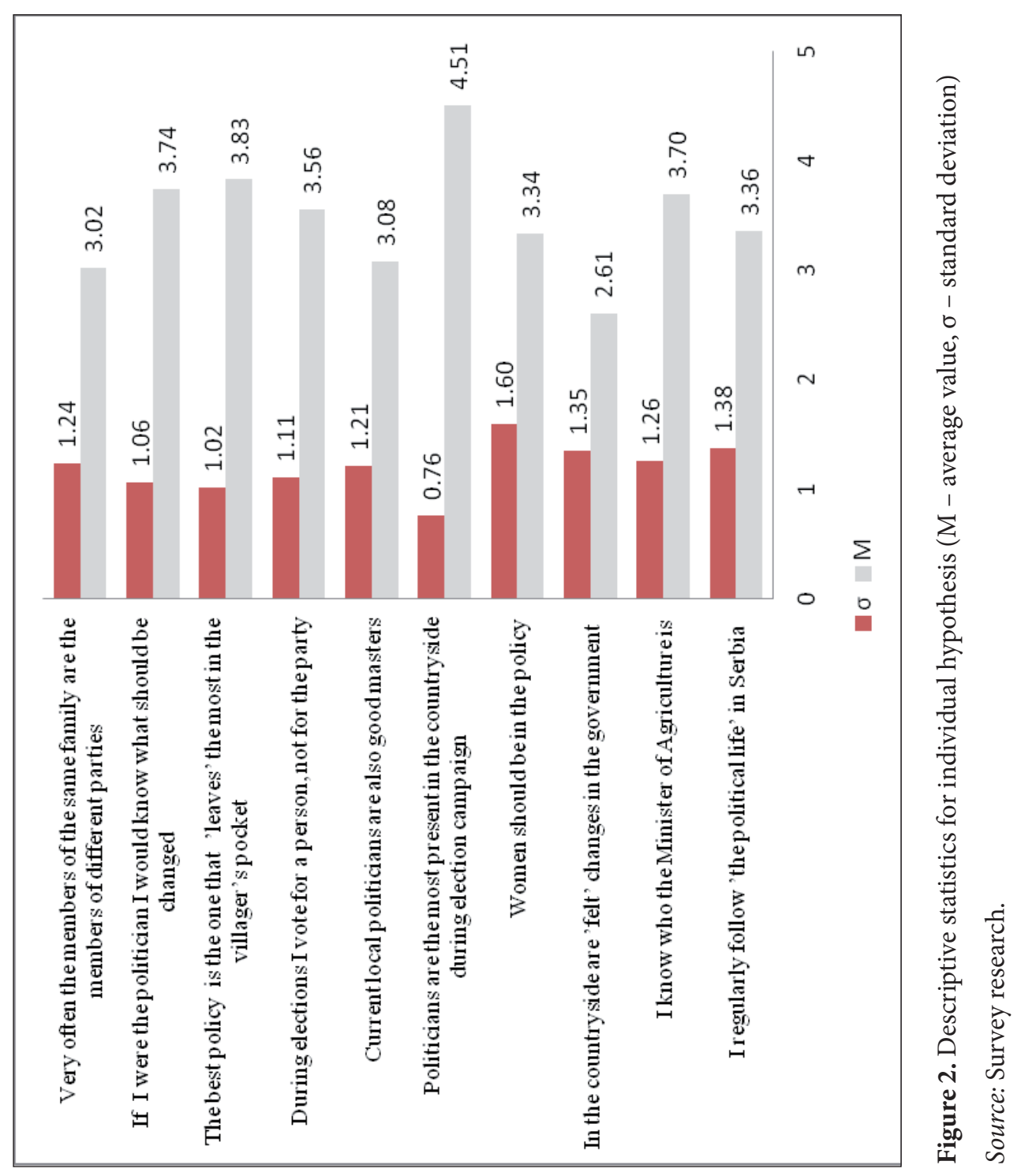


T-test showed the difference between gender, where the men were sure about their answer (Table 2). Naturally, politically engaged examinees were informed about it - who the minister of agriculture was - and they all agreed on that question $(\sigma=1.07)$ (Table 3$)$. Still, t-test showed that differences exist between the examinees who live on the hilly terrain and mountainous settlements, and those in the settlements in river valleys. Namely, the examinees who live at higher altitudes were more sure about the question who the minister of agriculture was $(\mathrm{M}=4.10)$ (Table 4). One-factory analysis of ANOVA variance, at the importance level $\mathrm{p}<0.01$; $F \geq 3.47$ find differences neither between the examinees of different age groups, nor among examinees of different activities.

Table 2. Differences concerning the inhabitants of rural settlements on the basis of gender $(M$-average value, $\sigma$-standard deviation, $t$-value, $p$-importancelevel $(\mathrm{p}<0.01))$

\begin{tabular}{|c|c|c|c|c|c|}
\hline Hypothesis & Gender & M & $\Sigma$ & $\mathrm{t}(105)$ & $\mathrm{P}$ \\
\hline \multirow{2}{*}{$\begin{array}{l}\text { I regularly follow 'the political } \\
\text { life' in Serbia }\end{array}$} & Male & 3.833 & 1.299 & \multirow{2}{*}{3.870} & \multirow{2}{*}{0.000} \\
\hline & Female & 2.863 & 1.296 & & \\
\hline \multirow{2}{*}{$\begin{array}{l}\text { I know who the Minister of } \\
\text { Agriculture is }\end{array}$} & Male & 4.148 & 1.219 & \multirow{2}{*}{3.623} & \multirow{2}{*}{0.000} \\
\hline & Female & 3.216 & 1.137 & & \\
\hline \multirow{2}{*}{$\begin{array}{l}\text { In the countryside are 'felt' } \\
\text { changes in the government }\end{array}$} & Male & 2.907 & 1.496 & \multirow{2}{*}{2.060} & \multirow{2}{*}{0.042} \\
\hline & Female & 2.294 & 1.101 & & \\
\hline \multirow{2}{*}{$\begin{array}{l}\text { Women should be in the } \\
\text { politics }\end{array}$} & Male & 3.056 & 1.642 & \multirow{2}{*}{1.412} & \multirow{2}{*}{0.161} \\
\hline & Female & 3.647 & 1.508 & & \\
\hline \multirow{2}{*}{$\begin{array}{l}\text { Politicians are the most present } \\
\text { in the countryside during } \\
\text { election campaign }\end{array}$} & Male & 4.500 & 0.927 & \multirow[b]{2}{*}{0.352} & \multirow[b]{2}{*}{0.726} \\
\hline & Female & 4.529 & 0.542 & & \\
\hline \multirow{2}{*}{$\begin{array}{l}\text { Current local politicians are } \\
\text { also good masters }\end{array}$} & Male & 3.093 & 1.404 & \multirow{2}{*}{0.169} & \multirow{2}{*}{0.866} \\
\hline & Female & 3.059 & 0.968 & & \\
\hline \multirow{2}{*}{$\begin{array}{l}\text { During elections, I vote for } \\
\text { a person, not for the party }\end{array}$} & Male & 3.278 & 1.106 & \multirow{2}{*}{2.643} & \multirow{2}{*}{0.009} \\
\hline & Female & 3.863 & 1.040 & & \\
\hline \multirow{2}{*}{$\begin{array}{l}\text { The best policy is the one that } \\
\text { 'leaves' the most in the villager's } \\
\text { pocket }\end{array}$} & Male & 3.833 & 1.112 & \multirow{2}{*}{0.206} & \multirow[b]{2}{*}{0.837} \\
\hline & Female & 3.824 & 0.932 & & \\
\hline
\end{tabular}


Table 2. Differences concerning the inhabitants

\begin{tabular}{|c|c|c|c|c|c|}
\hline Hypothesis & Gender & M & $\Sigma$ & $t(105)$ & $\mathrm{P}$ \\
\hline If I were the politician I would & Male & 4.111 & 0.839 & \multirow{2}{*}{3.966} & \multirow{2}{*}{0.000} \\
\hline know what should be changed & Female & 3.353 & 1.128 & & \\
\hline \multirow{2}{*}{$\begin{array}{l}\text { Very often, the members of the } \\
\text { same family are the members of } \\
\text { different parties }\end{array}$} & Male & 3.130 & 1.401 & \multirow[b]{2}{*}{0.920} & \multirow[b]{2}{*}{0.360} \\
\hline & Female & 2.902 & 1.044 & & \\
\hline
\end{tabular}

Source: Survey research.

Hypothesis 3: 'In the countryside are 'felt' changes in the government' Various types of the political changes in the government have also reflected the changes of agriculture in Europe; therefore, in rural area, it also happened at the end of the 20th century (Potter 1986; Robinson 1990; Champion \& Watkins 1991) and at the beginning of the 21st century. For that reason, the answer to this question given by the examinees was expected to be 'fully agreed'. However, the examinees were not able to estimate (2.61) if the changes in the government were 'felt' in the countryside, although this value gives the impression that they do not agree with it. T-test, carried out according to the gender criteria, showed that disagreement concerned women to the greatest extent. It showed significant statistic differences between the examinees, who were dealing with the politics and agreed, saying that, changes in the government were 'felt' in the countryside, in relation to those, who were not politically engaged and did not agree - they did not 'feel' changes in the government (Table 3). Such a difference was expected. If politically engaged ones did not agree with this hypothesis, it would mean that their political activity had no effect at all. T-test showed the significant statistic differences between the answers of those, who live in the valley and do not agree that changes in the government are not 'felt' in the countryside, and those, who are indecisive about the same question (Table 4). On the basis of the obtained results, we must admit that such a question could be understood in two different ways. Some of the examinees identified the changes in government with the changes of the system at the beginning of the last decade of the last century, and; according to them, they naturally 'feel' the changes in the government. While the other examinees thought about changes in the government which happened in the time when democratic society was established. 
Table 3. Differences concerning the inhabitants of rural settlements according to the political engagement $(\mathrm{M}$ - average value, $\sigma$ - standard deviation, T-value, $\mathrm{p}$ importance level $(\mathrm{p}<0.01))$.

\begin{tabular}{|c|c|c|c|c|c|}
\hline Hypothesis & $\begin{array}{c}\text { Political } \\
\text { engagement }\end{array}$ & M & $\Sigma$ & $\mathrm{t}(105)$ & $\mathrm{P}$ \\
\hline \multirow{2}{*}{$\begin{array}{l}\text { I regularly follow 'the } \\
\text { political life' in Serbia }\end{array}$} & Correct & 4.440 & 1.003 & \multirow{2}{*}{4.322} & \multirow{2}{*}{0.000} \\
\hline & Incorrect & 3.025 & 1.312 & & \\
\hline \multirow{2}{*}{$\begin{array}{l}\text { I know who the Minister } \\
\text { of Agriculture is }\end{array}$} & Correct & 4.360 & 1.075 & \multirow{2}{*}{2.566} & \multirow{2}{*}{0.012} \\
\hline & Incorrect & 3.488 & 1.253 & & \\
\hline \multirow{2}{*}{$\begin{array}{l}\text { In the countryside are } \\
\text { 'felt' changes in the } \\
\text { government }\end{array}$} & Correct & 3.680 & 1.435 & \multirow[b]{2}{*}{2.696} & \multirow[b]{2}{*}{0.008} \\
\hline & Incorrect & 2.275 & 1.136 & & \\
\hline \multirow{2}{*}{$\begin{array}{l}\text { Women should be in the } \\
\text { politics }\end{array}$} & Correct & 4.080 & 1.352 & \multirow{2}{*}{0.521} & \multirow{2}{*}{0.603} \\
\hline & Incorrect & 3.112 & 1.607 & & \\
\hline \multirow{2}{*}{$\begin{array}{l}\text { Politicians are the } \\
\text { most present in the } \\
\text { countryside during } \\
\text { election campaign }\end{array}$} & Correct & 4.160 & 1.179 & \multirow[b]{2}{*}{1.410} & \multirow[b]{2}{*}{0.161} \\
\hline & Incorrect & 4.625 & 0.537 & & \\
\hline \multirow{2}{*}{$\begin{array}{l}\text { Current local politicians } \\
\text { are also good masters }\end{array}$} & Correct & 3.720 & 1.429 & \multirow{2}{*}{2.573} & \multirow{2}{*}{0.012} \\
\hline & Incorrect & 2.875 & 1.060 & & \\
\hline \multirow{2}{*}{$\begin{array}{l}\text { During elections I vote } \\
\text { for a person, not for the } \\
\text { party }\end{array}$} & Correct & 2.880 & 1.166 & \multirow[t]{2}{*}{2.598} & \multirow[b]{2}{*}{0.011} \\
\hline & Incorrect & 3.775 & 1.006 & & \\
\hline \multirow{2}{*}{$\begin{array}{l}\text { The best policy is the } \\
\text { one that 'leaves' the most } \\
\text { in the villager's pocket }\end{array}$} & Correct & 4.040 & 0.935 & \multirow[b]{2}{*}{2.050} & \multirow[b]{2}{*}{0.043} \\
\hline & Incorrect & 3.763 & 1.046 & & \\
\hline \multirow{2}{*}{$\begin{array}{l}\text { If I were the politician } \\
\text { I would know what } \\
\text { should be changed }\end{array}$} & Correct & 4.160 & 0.898 & \multirow[b]{2}{*}{1.834} & \multirow[b]{2}{*}{0.070} \\
\hline & Incorrect & 3.613 & 1.073 & & \\
\hline \multirow{2}{*}{$\begin{array}{l}\text { Very often the members } \\
\text { of the same family are } \\
\text { the members of different } \\
\text { parties }\end{array}$} & Correct & 2.960 & 1.399 & \multirow[b]{2}{*}{1.202} & \multirow[b]{2}{*}{0.232} \\
\hline & Incorrect & 3.038 & 1.195 & & \\
\hline
\end{tabular}

Source: Survey research. 
Hypothesis 4: Women should deal with the politics

The biggest mutual disagreement was shown among the examinees concerning this hypothesis $(\sigma=1.60)$. As it was expected, politically engaged examinees and female respondents agreed with it. One-factor analysis of ANOVA variance, at importance level $\mathrm{p}<0.01 ; \mathrm{F} \geq 3.47$ found the differences between the examinees of different age groups (Table 5). Post hoc Tukey test showed that the examinees of the oldest age groups do not agree with this hypothesis (Table 7). The examinees, who did not agree with this hypothesis, shared patriarchal opinion that a woman should stay at home and look after the kids, and should not be in 'the political scene'. The societies of post-socialist countries of Europe originally were agrarian and then the socialists. Under pressure of tradition or socialist ideology, the women resources were engaged to the maximum extent (Blagojevic 2007). During the eighties of the 20th century, as a part of the socialist inheritance, about $27.0 \%$ of women were elected into the parliaments which was much more than $12.5 \%$ of women in the national parliament of the European Economic Community (today the part of European Union). After the changes in 1989, share of women in the whole region; that is, almost the whole Balkan Peninsula, drastically declined and they became invisible in the managing and deciding sphere. In former Socialist Republic of Yugoslavia, between 1979 and 1989, 17.0\% of women participated in the work of parliament, but during the elections in 1990, the participation of women was reduced to $13.0 \%$ in Slovenia, $4.5 \%$ in Croatia, 3.3\% in Montenegro, 2.9\% in Bosnia and Herzegovina and in Serbia it was only 1.6\% (Čičkarić 2009). During the nineties, because of stronger national policy, war, sanctions, isolation and economic collapse of the country, number of women in the politics was drastically reduced. After elections in 1992, in the Parliament of Serbia, only $4.0 \%$ of women were elected (UGS Nezavisnost 2001). The same phenomenon was noticed in the former Soviet Republics, East European countries, Caucasus region and Central Asia. This period is described in the feminist literature as 'masculinized democracy' (Einhorn 1993; Kligman 1996; Čičkarić 2009). Nowadays, women make one fifth (21.2\%) of board members in municipalities and cities (Republic of Serbia 2011) and one third (33.2\%) of the Parliament of the Republic of Serbia which puts Serbia in the 24th place in the world. At the tail of the table, there are the countries of Africa and Asia, populous 
India (10.0\%) (Beaman et al. 2010) and also Ukraine (9.4\%) and Hungary (8.8\%). In small Andorra (within its area and number of inhabitants) there is a half of women (50.0\%) engaged. Countries, which could be praised for the presence of women in the national parliaments, are; for example, Finland (42.5\%) and other North European countries, but also the countries which are not the most developed (http://www.ipu.org/wmn-e/classif.htm). Therefore, the examinees who live in the countryside of Serbia are not sure if women should be involved in the politics $(M=3.34)$.

Table 4. Differences concerning the inhabitants of rural settlements of Balkan Peninsula, based on the places of residence ( $\mathrm{M}$ - average value, $\sigma$ - standard deviation. T-value, p-importance level $(\mathrm{p}<0.01))$.

\begin{tabular}{|c|c|c|c|c|c|}
\hline Hypothesis & $\begin{array}{l}\text { Places of } \\
\text { residence }\end{array}$ & M & $\Sigma$ & $\mathrm{t}(105)$ & $\mathrm{P}$ \\
\hline \multirow{2}{*}{$\begin{array}{l}\text { I regularly follow 'the } \\
\text { political life' in Serbia }\end{array}$} & Valley & 3.264 & 1.332 & \multirow{2}{*}{0.850} & \multirow{2}{*}{0.397} \\
\hline & Hill & 3.462 & 1.434 & & \\
\hline \multirow{2}{*}{$\begin{array}{l}\text { I know who the Minister } \\
\text { of Agriculture is }\end{array}$} & Valley & 3.302 & 1.218 & \multirow{2}{*}{3.220} & \multirow{2}{*}{0.002} \\
\hline & Hill & 4.096 & 1.192 & & \\
\hline \multirow{2}{*}{$\begin{array}{l}\text { In the countryside are } \\
\text { 'felt' changes in the } \\
\text { government }\end{array}$} & Valley & 2.264 & 1.227 & \multirow[b]{2}{*}{2.597} & \multirow[b]{2}{*}{0.011} \\
\hline & Hill & 2.962 & 1.386 & & \\
\hline \multirow{2}{*}{$\begin{array}{l}\text { Women should be in the } \\
\text { politics }\end{array}$} & Valley & 3.113 & 1.589 & \multirow{2}{*}{1.202} & \multirow{2}{*}{0.232} \\
\hline & Hill & 3.577 & 1.589 & & \\
\hline \multirow{2}{*}{$\begin{array}{l}\text { Politicians are the } \\
\text { most present in the } \\
\text { countryside during } \\
\text { election campaign }\end{array}$} & Valley & 4.472 & 0.749 & \multirow[b]{2}{*}{0.480} & \multirow[b]{2}{*}{0.632} \\
\hline & Hill & 4.558 & 0.777 & & \\
\hline \multirow{2}{*}{$\begin{array}{l}\text { Current local politicians } \\
\text { are also good masters }\end{array}$} & Valley & 2.830 & 1.252 & \multirow{2}{*}{2.323} & \multirow{2}{*}{0.022} \\
\hline & Hill & 3.327 & 1.115 & & \\
\hline \multirow{2}{*}{$\begin{array}{l}\text { During elections I vote } \\
\text { for a person, not for the } \\
\text { party }\end{array}$} & Valley & 3.585 & 1.167 & \multirow[b]{2}{*}{0.150} & \multirow[b]{2}{*}{0.881} \\
\hline & Hill & 3.538 & 1.056 & & \\
\hline \multirow{2}{*}{$\begin{array}{l}\text { The best policy is the } \\
\text { one that 'leaves' the most } \\
\text { in the villager's pocket }\end{array}$} & Valley & 4.019 & 0.909 & \multirow[b]{2}{*}{1.972} & \multirow[b]{2}{*}{0.051} \\
\hline & Hill & 3.635 & 1.103 & & \\
\hline
\end{tabular}


Table 4. Differences concerning the inhabitants

\begin{tabular}{|c|c|c|c|c|c|}
\hline Hypothesis & $\begin{array}{l}\text { Places of } \\
\text { residence }\end{array}$ & M & $\Sigma$ & $\mathrm{t}(105)$ & $\mathrm{P}$ \\
\hline \multirow{2}{*}{$\begin{array}{l}\text { If I were the politician } \\
\text { I would know what } \\
\text { should be changed }\end{array}$} & Valley & 3.679 & 1.015 & \multirow[b]{2}{*}{0.508} & \multirow[b]{2}{*}{0.613} \\
\hline & Hill & 3.808 & 1.103 & & \\
\hline \multirow{2}{*}{$\begin{array}{l}\text { Very often the members } \\
\text { of the same family are } \\
\text { the members of different } \\
\text { parties }\end{array}$} & Valley & 2.962 & 1.240 & \multirow[b]{2}{*}{0.491} & \multirow[b]{2}{*}{0.624} \\
\hline & Hill & 3.077 & 1.250 & & \\
\hline
\end{tabular}

Source: Survey research.

Hypothesis 5: Politicians are the most present in the countryside during the election campaign

This hypothesis distinguished itself as the only one about which everybody 'fully agreed' taking the average value, as well as, the value of standard deviation $(\sigma=0.76)$ into consideration. Less disapproval was shown during informal communication with the examinees who were politically engaged. All tests, conducted additionally, did not find any significant statistic differences among certain categories of the examinees. In the time of polling campaign, they mostly rely on public rallies, direct mailing, TV appearance (but no ads), phone banks and door-to-door canvassing (Kendall et al. 2013). More examinees based their comments on the idea that it would be useful if the governing parties would visit the rural settlements when it was not time for campaign, in order to improve the quality of life in the countryside. As one of the examinees said: 'During the campaign they can only give promises that something will be done. If during their mandate they had been reminded about our problems, they would have been able to help us.' 
Table 5. One-factor analysis of differences between the inhabitants of rural settlements of Balkan based on the age of examinees ( $\mathrm{M}$-average value, $\sigma$-standard deviation, for F $(4,100)$, critic values according to Snedecor \& Cochran table (1980), $\mathrm{p}<0.01 ; \mathrm{F} \geq 3.47 ; \mathrm{p}<0.05 ; \mathrm{F} \geq 2.44)$.

\begin{tabular}{|c|c|c|c|c|c|}
\hline Hypothesis & Age & $\mathrm{M}$ & $\sigma$ & $\mathrm{F}$ & $\mathrm{p}$ \\
\hline \multirow{5}{*}{$\begin{array}{l}\text { I regularly follow 'the } \\
\text { political life' in Serbia }\end{array}$} & $20-29$ & 3.250 & 1.485 & \multirow{5}{*}{2.640} & \multirow{5}{*}{0.0382} \\
\hline & $30-39$ & 2.885 & 1.479 & & \\
\hline & $40-49$ & 3.043 & 1.224 & & \\
\hline & $50-59$ & 3.950 & 1.050 & & \\
\hline & $60+$ & 3.750 & 1.422 & & \\
\hline \multirow{5}{*}{$\begin{array}{l}\text { I know who the Minister of } \\
\text { Agriculture is }\end{array}$} & $20-29$ & 3.583 & 1.311 & \multirow{5}{*}{1.455} & \multirow{5}{*}{0.2218} \\
\hline & $30-39$ & 3.538 & 1.392 & & \\
\hline & $40-49$ & 3.391 & 1.305 & & \\
\hline & $50-59$ & 4.250 & 1.020 & & \\
\hline & $60+$ & 3.750 & 1.189 & & \\
\hline \multirow{5}{*}{$\begin{array}{l}\text { In the countryside are 'felt' } \\
\text { changes in the government }\end{array}$} & $20-29$ & 2.667 & 1.231 & \multirow{5}{*}{1.430} & \multirow{5}{*}{0.2295} \\
\hline & $30-39$ & 2.385 & 1.235 & & \\
\hline & $40-49$ & 2.261 & 1.054 & & \\
\hline & $50-59$ & 3.150 & 1.309 & & \\
\hline & $60+$ & 2.708 & 1.706 & & \\
\hline \multirow{5}{*}{$\begin{array}{l}\text { Women should be in the } \\
\text { politics }\end{array}$} & $20-29$ & 3.000 & 1.477 & \multirow{5}{*}{6.033} & \multirow{5}{*}{0.0002} \\
\hline & $30-39$ & 4.000 & 1.233 & & \\
\hline & $40-49$ & 2.739 & 1.602 & & \\
\hline & $50-59$ & 2.450 & 1.669 & & \\
\hline & $60+$ & 4.125 & 1.361 & & \\
\hline \multirow{5}{*}{$\begin{array}{l}\text { Politicians are the most } \\
\text { present in the countryside } \\
\text { during election campaign }\end{array}$} & $20-29$ & 4.500 & 0.905 & \multirow{5}{*}{0.3408} & \multirow{5}{*}{0.8498} \\
\hline & $30-39$ & 4.423 & 0.945 & & \\
\hline & $40-49$ & 4.478 & 0.511 & & \\
\hline & $50-59$ & 4.500 & 0.946 & & \\
\hline & $60+$ & 4.667 & 0.482 & & \\
\hline
\end{tabular}


Table 5. One-factor analysis of differences between the inhabitants

\begin{tabular}{|c|c|c|c|c|c|}
\hline Hypothesis & Age & M & $\sigma$ & $\mathrm{F}$ & $\mathrm{p}$ \\
\hline \multirow{5}{*}{$\begin{array}{l}\text { Current local politicians are } \\
\text { also good masters }\end{array}$} & $20-29$ & 2.917 & 1.621 & \multirow{5}{*}{2.2302} & \multirow{5}{*}{0.0711} \\
\hline & $30-39$ & 2.731 & 1.079 & & \\
\hline & $40-49$ & 2.913 & 1.041 & & \\
\hline & $50-59$ & 3.100 & 1.071 & & \\
\hline & $60+$ & 3.667 & 1.239 & & \\
\hline \multirow{5}{*}{$\begin{array}{l}\text { During elections I vote for } \\
\text { a person, not for the party }\end{array}$} & $20-29$ & 3.417 & 0.996 & \multirow{5}{*}{3.9016} & \multirow{5}{*}{0.0055} \\
\hline & $30-39$ & 3.615 & 1.267 & & \\
\hline & $40-49$ & 4.261 & 0.810 & & \\
\hline & $50-59$ & 3.250 & 1.070 & & \\
\hline & $60+$ & 3.167 & 1.007 & & \\
\hline \multirow{5}{*}{$\begin{array}{l}\text { The best policy is the one } \\
\text { that 'leaves' the most in the } \\
\text { villager's pocket }\end{array}$} & $20-29$ & 4.083 & 0.793 & \multirow{5}{*}{1.0155} & \multirow{5}{*}{0.4031} \\
\hline & $30-39$ & 3.654 & 1.198 & & \\
\hline & $40-49$ & 3.609 & 1.196 & & \\
\hline & $50-59$ & 3.850 & 0.875 & & \\
\hline & $60+$ & 4.083 & 0.830 & & \\
\hline \multirow{5}{*}{$\begin{array}{l}\text { If I were the politician } \\
\text { I would know what should } \\
\text { be changed }\end{array}$} & $20-29$ & 3.917 & 0.515 & \multirow{5}{*}{0.3379} & \multirow{5}{*}{0.8518} \\
\hline & $30-39$ & 3.731 & 1.116 & & \\
\hline & $40-49$ & 3.565 & 1.080 & & \\
\hline & $50-59$ & 3.700 & 0.923 & & \\
\hline & $60+$ & 3.875 & 1.296 & & \\
\hline \multirow{5}{*}{$\begin{array}{l}\text { Very often, the members } \\
\text { of the same family are the } \\
\text { members of different parties }\end{array}$} & $20-29$ & 3.667 & 1.073 & \multirow{5}{*}{2.2325} & \multirow{5}{*}{0.0708} \\
\hline & $30-39$ & 3.385 & 1.267 & & \\
\hline & $40-49$ & 2.696 & 0.926 & & \\
\hline & $50-59$ & 2.800 & 1.322 & & \\
\hline & $60+$ & 2.792 & 1.351 & & \\
\hline
\end{tabular}

Source: Survey research.

Hypothesis 6: Current local politicians are also good masters

The examinees did not know whether the current politicians are also good masters $(\mathrm{M}=3.08)$ and; simultaneously, they do not agree with 
this question ( $\sigma=1.21)$. T-test, made according to the criteria of political engagement, showed significant statistic differences between the examinees who are dealing with the politics and agree with hypothesis that 'the current politicians are good masters', and those who are neither politically engaged, nor sure to know if the current local politicians are also good masters (Table 5). In relation to the others, the agriculturalists agreed with this hypothesis $(\mathrm{M}=3.63, \sigma=1.03)$ (Table 6). It is obvious that politically engaged people from 'their orders' are really good masters. Politically engaged ones claimed that they prefer to give functions to the capable 'good master' because, as he has got the reputation based on well 'running' of his own estate, he would behave conscientiously toward entrusted functions. Those who are not politically engaged will prove their attitude by the fact that 'the politicians are good masters also, the results of their work would be visible and people would be more satisfied'. It is interesting that links between reputations of organizations and their leaders have been claimed but never demonstrated empirically (Davies \& Main 2010).

Table 6. One-factor analysis of differences between the inhabitants of rural settlements of Balkan based on their activity (M-average value, $\sigma$-standard deviation, for $\mathrm{F}$ $(5,100)$, critic values according to Snedecor \& Cochran table (1980), $\mathrm{p}<0.01 ; \mathrm{F} \geq 3.47$; $\mathrm{p}<0.05 ; \mathrm{F} \geq 2.44)$

\begin{tabular}{|c|c|c|c|c|c|}
\hline Hypothesis & Activity & $\mathrm{M}$ & $\sigma$ & $\mathrm{F}$ & $\mathrm{p}$ \\
\hline \multirow{6}{*}{$\begin{array}{l}\text { I regularly follow } \\
\text { 'the political life' } \\
\text { in Serbia }\end{array}$} & Employed & 3.441 & 1.440 & \multirow{6}{*}{4.4529} & \multirow{6}{*}{0.0011} \\
\hline & Farmer, but employed & 2.667 & 1.435 & & \\
\hline & Farmer & 4.000 & 2.667 & & \\
\hline & Retired & 2.600 & 1.265 & & \\
\hline & Unemployed & 3.400 & 0.966 & & \\
\hline & Other & 2.000 & 1.549 & & \\
\hline \multirow{6}{*}{$\begin{array}{l}\text { I know who } \\
\text { the Minister of } \\
\text { Agriculture is }\end{array}$} & Employed & 3.735 & 1.463 & \multirow{6}{*}{0.4983} & \multirow{6}{*}{0.7768} \\
\hline & Farmer, but employed & 3.500 & 1.087 & & \\
\hline & Farmer & 3.879 & 1.269 & & \\
\hline & Retired & 3.300 & 1.160 & & \\
\hline & Unemployed & 3.800 & 1.033 & & \\
\hline & Other & 3.333 & 1.033 & & \\
\hline
\end{tabular}


Table 6. One-factor analysis of differences between the inhabitants

\begin{tabular}{|c|c|c|c|c|c|}
\hline Hypothesis & Activity & $M$ & $\sigma$ & $\mathrm{F}$ & $\mathrm{p}$ \\
\hline \multirow{6}{*}{$\begin{array}{l}\text { In the } \\
\text { countryside are } \\
\text { 'felt' changes in } \\
\text { the government }\end{array}$} & Employed & 2.647 & 1.228 & \multirow{6}{*}{1.0422} & \multirow{6}{*}{0.3973} \\
\hline & Farmer, but employed & 2.500 & 1.382 & & \\
\hline & Farmer & 2.848 & 1.603 & & \\
\hline & Retired & 2.200 & 1.135 & & \\
\hline & Unemployed & 2.800 & 1.229 & & \\
\hline & Other & 1.667 & 0.516 & & \\
\hline \multirow{6}{*}{$\begin{array}{l}\text { Women should } \\
\text { be in the politics }\end{array}$} & Employed & 3.618 & 1.371 & \multirow{6}{*}{1.1696} & \multirow{6}{*}{0.3296} \\
\hline & Farmer, but employed & 3.250 & 1.765 & & \\
\hline & Farmer & 2.909 & 1.739 & & \\
\hline & Retired & 3.300 & 1.829 & & \\
\hline & Unemployed & 3.400 & 1.506 & & \\
\hline & Other & 4.333 & 1.211 & & \\
\hline \multirow{6}{*}{$\begin{array}{l}\text { Politicians } \\
\text { are the most } \\
\text { present in the } \\
\text { countryside } \\
\text { during election } \\
\text { campaign }\end{array}$} & Employed & 4.441 & 0.927 & \multirow{6}{*}{1.3941} & \multirow{6}{*}{0.2330} \\
\hline & Farmer, but employed & 4.417 & 0.900 & & \\
\hline & Farmer & 4.727 & 0.452 & & \\
\hline & Retired & 4.700 & 0.483 & & \\
\hline & Unemployed & 4.100 & 0.994 & & \\
\hline & Other & 4.667 & 0.516 & & \\
\hline \multirow{6}{*}{$\begin{array}{l}\text { Current local } \\
\text { politicians } \\
\text { are also good } \\
\text { masters }\end{array}$} & Employed & 2.853 & 1.209 & \multirow{6}{*}{2.4863} & \multirow{6}{*}{0.0364} \\
\hline & Farmer, but employed & 3.000 & 1.414 & & \\
\hline & Farmer & 3.636 & 1.025 & & \\
\hline & Retired & 2.500 & 0.972 & & \\
\hline & Unemployed & 2.700 & 1.337 & & \\
\hline & Other & 3.000 & 1.095 & & \\
\hline \multirow{6}{*}{$\begin{array}{l}\text { During } \\
\text { elections, I vote } \\
\text { for a person, not } \\
\text { for the party }\end{array}$} & Employed & 3.588 & 1.131 & \multirow{6}{*}{2.0891} & \multirow{6}{*}{0.0730} \\
\hline & Farmer, but employed & 4.083 & 1.084 & & \\
\hline & Farmer & 3.758 & 1.146 & & \\
\hline & Retired & 3.000 & 0.943 & & \\
\hline & Unemployed & 3.200 & 0.919 & & \\
\hline & Other & 2.833 & 0.753 & & \\
\hline
\end{tabular}


Table 6. One-factor analysis of differences between the inhabitants

\begin{tabular}{llrlrl}
\hline \multicolumn{1}{c}{ Hypothesis } & \multicolumn{1}{c}{ Activity } & $\mathrm{M}$ & $\sigma$ & $\mathrm{F}$ & $\mathrm{p}$ \\
\hline & Employed & 3.588 & 1.158 & & \\
The best policy & Farmer, but employed & 4.333 & 1.231 & & \\
is the one that & Farmer & 3.727 & 0.839 & & \\
'leaves' the most & Retired & 4.200 & 0.789 & & 0.2035 \\
in the villager's & Unemployed & 4.100 & 0.738 & & \\
pocket & Other & 4.000 & 1.265 & & \\
& Employed & 3.618 & 0.922 & & \\
If I were the & Farmer, but employed & 4.000 & 1.477 & & \\
politician & Farmer & 4.091 & 0.914 & & \\
I would know & Retired & 2.900 & 0.994 & & \\
what should be & Unemployed & 4.000 & 0.667 & & \\
changed & Other & 3.000 & 1.265 & & \\
& Employed & 3.147 & 1.306 & & \\
Very often, the & Farmer, but employed & 3.167 & 1.403 & & \\
members of the & Farmer & 3.333 & 1.051 & \multirow{2}{*}{2.9863} & 0.0149 \\
same family are & Retired & 1.900 & 0.876 & & \\
the members of & Unemployed & 3.000 & 1.155 & & \\
different parties & Uner & 2.167 & 1.169 & & \\
& Other & & &
\end{tabular}

Source: Survey research.

Hypothesis 7: At the elections, I vote for a person, not for the party

The reputations of leader and party are highly correlated (Davies and Mian 2010). In recent years, there has been a general trend towards granting party members greater influence in the choice of their leader (Cross and Blais 2012). The analysis of hypothesis 7, showed how important is the choice of candidate in the rural settlements of the Balkan Peninsula. Almost all examinees agreed with this hypothesis $(M=3.56)$. T-test showed significant statistic differences between male and female examinees and the examinees who are and are not engaged in the party. While the men were indecisive, female examinees agreed with this hypothesis $(M=3.86)$ and agreed mostly unanimously because the value of standard deviation was slightly above the limited value $1(\sigma=1.04)$. The examinees who are not engaged in the party, agreed with the fact that; at the elections, they 
vote for a man, not for the party $(\mathrm{M}=3.76, \sigma=1.01)$, while the examinees engaged in the party were not sure about this fact. Naturally, it was expected from them to vote for the party where they belong. Therefore, the values which pointed out disagreement were expected. Having confidence in a man, a leader, is very important for stability of some government $(\mathrm{Li}$ 2011). One-factor analysis of ANOVA variance was at importance level $\mathrm{p}<0.01 ; \mathrm{F} \geq 3.47$ and established differences between the examinees of different age groups. Post-hoc Tukey test helped to identify the groups of examinees which distinguished themselves. Accordingly, the biggest differences in opinion existed between the age group from 40 to 49 years old and the oldest age groups (50-59, 60+). Members of this age group (40-49) agreed $(M=4.26)$ with this hypothesis (Table 5) which, shows that there are minimum politically engaged examinees in their orders (Table 7).

Table 7. Post-hoc Tukey HSD test for hypothesis where the one-factor analysis ANOVA established the differences in opinions of the examinees in different age groups (MSE - mean square error, q-relevant critical value of the studentized range statistic, $\mathrm{n}$-number of scores used in calculating the group means of interest, according to the table from http://www.stat.duke.edu/courses/Spring98/sta110c/qtable.html, $\alpha>0.05$, sign not important)

\begin{tabular}{lccc}
\hline $\begin{array}{l}\text { Tukey } \\
\text { HSD }\end{array}$ & $H S D=q * \sqrt{\frac{M S E}{n}}$ & $\begin{array}{c}\text { Women should be } \\
\text { in the politics }\end{array}$ & $\begin{array}{c}\text { During elections I vote for } \\
\text { a person, not for the party }\end{array}$ \\
q (from the table) \\
MSE \\
N
\end{tabular}


Table 7. Post-hoc Tukey HSD test

\begin{tabular}{lccc}
\hline $\begin{array}{l}\text { Tukey } \\
\text { HSD }\end{array}$ & $H S D=q * \sqrt{\frac{M S E}{n}}$ & $\begin{array}{c}\text { Women should be } \\
\text { in the politics }\end{array}$ & $\begin{array}{c}\text { During elections I vote for } \\
\text { a person, not for the party }\end{array}$ \\
q (from the table) & \multicolumn{2}{c}{$3.92 \alpha>0.05$} \\
MSE \\
N \\
HSD
\end{tabular}

Source: Survey research.

Hypothesis 8: The best policy is the one which 'leaves' the most in the pocket of the peasants

The examinees agreed $(\mathrm{M}=3.83, \sigma=1.02)$ with this hypothesis (Figure 2) that was confirmed by t-test, because no significant statistic differences were seen between any group of examinees, as well as, one-factor analysis of ANOVA variant on the importance level $\mathrm{p}<0.01$; $\mathrm{F} \geq 3.47$. Perhaps, this hypothesis is the best example of how little the politics, its ideology, program mean to the inhabitants of the Balkan rural settlements, and which one is the best according to them. However, a similar situation was established all over the world, also. For example, in populous, agrarian India, the voting behavior has undergone change over time, as voters have become more and more conscious of the potential for a better life offered by economic reforms leading to faster growth and improved economic fortunes (Gupta and Panagrya 2012).

Hypothesis 9: If I were the politician, I would know exactly what should be changed.

The examinees quite agree about this hypothesis $(M=3.74, \sigma=1.06)$. T-test showed significant statistic differences between arithmetic means of 
male and female examinees. Therefore, men were more sure $(\mathrm{M}=4.11)$ and mutually more agree $(\sigma=0.84)$ in relation to indecisive women $(M=3.35$, $\sigma=1.13$ ). One-factor analysis of ANOVA variance was at importance level $\mathrm{p}<0.01 ; \mathrm{F} \geq 3.47$ and established significant statistic differences in perception of this hypothesis with the examinees of different activities. By Post-hoc Tukey test deviations with the employed, the unemployed and agriculturalists were found (Table 8). They were more decisive in agreeing with this hypothesis in relation to the others. Although there were some attempts to engage people, who were not in the politics, in the process of deciding, the investigations have shown that this was not appropriate (Clarke 2011).

Table 8. Post-hoc Tukey HSD test for hypothesis where the one-factor analysis ANOVA established differences in opinions of examinees of different activities (MSE - mean square error, q-relevant critical value of the studentized range statistic, $\mathrm{n}$-number of scores used in calculating the group means of interest, according to the table from http://www.stat.duke.edu/courses/Spring98/sta110c/qtable.html, $\alpha>0.05$, sign not important)

\begin{tabular}{|c|c|c|c|c|}
\hline Tukey HSD & $H S D=q *$ & $\sqrt{\frac{M S E}{n}}$ & $\begin{array}{l}\text { I regularly follow } \\
\text { 'the political life' } \\
\text { in Serbia }\end{array}$ & $\begin{array}{l}\text { If I were the politician } \\
\text { I would know what } \\
\text { should be changed }\end{array}$ \\
\hline \multicolumn{3}{|c|}{$\mathrm{q}$ (from the table) } & \multicolumn{2}{|c|}{$4.10 \alpha>0.05$} \\
\hline \multicolumn{3}{|l|}{ MSE } & \multicolumn{2}{|r|}{1.007} \\
\hline \multicolumn{3}{|l|}{$\mathrm{N}$} & \multicolumn{2}{|c|}{21.0} \\
\hline \multicolumn{3}{|l|}{ HSD } & 1.1440 & 0.8978 \\
\hline & & & \multicolumn{2}{|c|}{ Differences in mean values } \\
\hline Employed & $\begin{array}{l}\text { Farmer, but } \\
\text { employed }\end{array}$ & & -1.400 & -1.000 \\
\hline Employed & Farmer & & 0.600 & 0.100 \\
\hline Employed & Retired & & -2.000 & -1.091 \\
\hline Employed & Unemployed & & -0.667 & -1.000 \\
\hline Employed & Other & & -1.441 & -0.618 \\
\hline $\begin{array}{l}\text { Farmer, but } \\
\text { employed }\end{array}$ & Farmer & & 0.800 & 1.100 \\
\hline
\end{tabular}


Table 8. Post-hoc Tukey HSD test

\begin{tabular}{|c|c|c|c|c|}
\hline Tukey HSD & $H S D=q *$ & $\sqrt{\frac{M S E}{n}}$ & $\begin{array}{l}\text { I regularly follow } \\
\text { 'the political life' } \\
\text { in Serbia }\end{array}$ & $\begin{array}{l}\text { If I were the politician } \\
\text { I would know what } \\
\text { should be changed }\end{array}$ \\
\hline \multirow{2}{*}{\multicolumn{3}{|c|}{$\begin{array}{l}\mathrm{q} \text { (from the table) } \\
\text { MSE }\end{array}$}} & \multicolumn{2}{|c|}{$4.10 \alpha>0.05$} \\
\hline & & & 1.635 & 1.007 \\
\hline \multicolumn{3}{|l|}{$\mathrm{N}$} & \multicolumn{2}{|r|}{21.0} \\
\hline \multirow[t]{2}{*}{ HSD } & & & 1.1440 & 0.8978 \\
\hline & & & \multicolumn{2}{|c|}{ Differences in mean values } \\
\hline $\begin{array}{l}\text { Farmer, but } \\
\text { employed }\end{array}$ & Retired & & -0.600 & -0.091 \\
\hline $\begin{array}{l}\text { Farmer, but } \\
\text { employed }\end{array}$ & Unemployed & & 0.733 & 0.000 \\
\hline $\begin{array}{l}\text { Farmer, but } \\
\text { employed }\end{array}$ & Other & & 0.041 & 0.382 \\
\hline Farmer & Retired & & -1.400 & -1.191 \\
\hline Farmer & Unemployed & & -0.067 & -1.100 \\
\hline Farmer & Other & & -0.841 & 0.718 \\
\hline Retired & Unemployed & & 1.333 & 0.091 \\
\hline Retired & Other & & 0.559 & 0.473 \\
\hline Unemployed & Other & & -0.774 & 0.382 \\
\hline
\end{tabular}

Source: Survey research.

Hypothesis 10: The members of the same family are very often the members of different parties

The purpose of this hypothesis was to illustrate how the inhabitants from rural settlements of Serbia use the politics for fulfilling the needs of personal and professional lives, or some of 'third nature.' The parties are not infrequently perceived as a shortcut for accomplishing of personal goals (Andersen and Tobiasen 2011; Hopkin 2012). The examinees replied that they were not sure about this hypothesis. The theme of some new work could refer to the sincerity of the examinees and their willingness to admit something and believe that investigation was anonymous, so data would be used only for the scientific purpose. One-factor analysis 
of ANOVA variance at importance value $\mathrm{p}<0.05 ; \mathrm{F} \geq 2.44$ established differences between the examinees of different activities (Table 5). Namely, the pensioners and examinees classified within the others' category, did not agree with this hypothesis. The pensioners from here spent a greater part of their working experience in one-party society, where it was not possible to apply such way of behavior. The examinees within the 'others' category were, for example, women who have spent their life working only for their family as housewives. In the countryside of Serbia, such women were not socially active persons, so their confusion was really justified when they were asked this question.

\section{Conclusions}

Exactly 105 examinees from the area of Serbia evaluated the hypothesis formed on the basis of the opinion of a small number of politically inactive agriculturalists. They agreed the most about hypothesis that 'the politicians were present the most in the countryside during election campaign'. They did not agree with hypothesis that "changes in government were 'felt' in the countryside". T-test identified disagreement among different gender concerning regular following of political life in Serbia, knowledge about who the minister of agriculture was and regarding knowledge about what should be changed if the examinee was in the place of the politician. In all three cases, men were more sure about their activities, knowledge and readiness. Women agreed only about the statement that at the elections they voted for a person, not for the party. T-test established disagreement of the examinees who were engaged in the politics in relation to those who were not. Politically engaged examinees agreed that they regularly followed the political life in Serbia, they knew who the ministry of agriculture was, that in the countryside were 'felt' changes in the government, that the actual politicians were good masters but at the elections they voted for the party, not for a person. The minimum differences were found between the examinees who lived in the valley in relation to the examinees from the hills and mountainous areas. The examinees who lived in the valley were less sure about who the minister of agriculture was and did not agree that in the countryside they 'felt' changes in government. One-factor analysis of ANOVA variance, at importance value $\mathrm{p}<0.05 ; \mathrm{F} \geq 2.44$, has established differences between the examinees of different age with hypothesis 'women 
should be engaged in the politics' and 'at elections I vote for a person, not the party. The differences of the examinees according to their activities were noticed with hypothesis 'I regularly follow the political life in Serbia' and 'If I were the politician I would know exactly what should be changed'.

The presence of the examinees of different activities in random sample illustrated that the countryside is not a place where only the agriculturalists live. Most of rural settlements of Serbia are quite urbanized and younger inhabitants use all available technical possibilities of providing information. However, from all inhabitants in rural settlements, the agriculturalists follow the political life the most and they are well informed about it. The politics is often a topic of their conversations and they have their own opinion, as well as, the know exactly what they would change if they were in the place of a politician. The agriculturalists were distinguished as the lowest number of those believing that women should be engaged in the politics but they were not sure that the best policy is the one which 'leaves the most in their pocket'.

\section{Acknowledges}

This paper is part of the Project No. 114-451-3938/2013-02 funded by the Provincial Secretariat for Science and Technological Development of the Vojvodina Province, Serbia and the Project funded by the JP 'Službeni glasnik'; National parks of Serbia and Geographical Institute "Jovan Cvijić" SASA. The authors are grateful to the reviewers, whose comments and criticisms have ensured the quality of the paper. We express our special acknowledgements to all examinees who spent their time on filling this questionnaire.

\section{References}

Andersen, J. G., Tobiasen, M., 2011. 'Who are these political consumers anyway? Survey evidence from Denmark'. Micheletti, Føllesdal and Stolle, eds, Politics, Products, and Markets, 203: 22.

Bagozzi, R. P., 1981. 'Evaluating Structural Equation Models with Unobservable Variables and Measurement Error: A Comment'. Journal of Marketing Research, 18: 380 . 
Beaman, L., Duflo, E., Pande, R., Topalova, P., 2010. Political reservation and substantive representation: Evidence from Indian village councils.

Champion, T., Watkins, C., 1991. People in the countryside: studies of social change in rural Britain. Paul Chapman Publishing Ltd.

Čičkarić, L., 2009. 'Politička participacija i reprezentacija žena u zemljama postsocijalističke Evrope' [Political participation and representation of women in post-socialist countries of Europe], Sociološki pregled, Vol. XLIII (3): 343-359.

Clarke, J., 2010. 'Enrolling ordinary people: governmental strategies and the avoidance of politics?', Citizenship studies, Vol. 14(6): 637-650.

Cross, W., Blais, A., 2012. 'Who selects the party leader?', Party Politics, Vol. 18 (2): $127-150$.

Davies, G., Mian, T., 2010. 'The reputation of the party leader and of the party being led', European Journal of Marketing, Vol. 44 (3/4): 331-350.

Gupta, P., Panagariya, A., 2012. 'Economic Reforms and Election Outcomes', India's Reforms: How They Produced Inclusive Growth, p. 51.

Hadjar, A., Schlapbach, F., 2009. 'Educational expansion and interest in politics in temporal and cross-cultural perspective: a comparison of West Germany and Switzerland', European sociological review, Vol. 25 (3): 271-286.

Hopkin, J., 2012. Paying for party response. How Political Parties Respond to Voters, p. 176.

Einhorn, B., 1993. Cinderella Goes to Market: Citizenship, Gender, and Women's Movements in East Central Europe. New York: Verso.

Kendall, C., Nannicini, T., Trebbi, F., 2013. How do voters respond to information? Evidence from a randomized campaign. No. w18986. National Bureau of Economic Research.

Kligman, G., 1996. Women and the Negotiation of Identity in Post-communist Eastern Europe. In: Bonnell, V. E. (ed.), Identities in Transition, University of California, Berkeley, CA, pp. 68-91.

Li, L., 2011. 'Distrust in government leaders, demand for leadership change, and preference for popular elections in rural China', Political Behavior, Vol. 33 (2): 291-311.

Pearson, E. S., Hartley, H. O., (eds) 1966. Biometrika Tables for Statisticians, Vol. 1: 146, third edition.

Potter, C., 1986. 'Processes of countryside change in lowland England', Journal of Rural Studies, Vol. 2(3): 187-195. 
Prior, M., 2010. 'You've either got it or you don't? The stability of political interest over the life cycle', The Journal of Politics, Vol. 72 (03): 747-766.

Republika Srbija, 2011: Odbornici skupština opština i gradova, prema polu i godinama života, 2008, Opštine i regioni u Republici Srbiji 2011 [Councilors of the municipalities and cities by gender and age, 2008, Municipalities and regions in the Republic of Serbia in 2011] Beograd: Republički zavod za statistiku.

Robinson, G., 1990. Conflict and change in the countryside. Rural society, economy and planning in the developed world. Belhaven Press.

Snedecor, G. W., Cochran, W. G., 1980. Statistical Methods. Ames, Iowa: Iowa State University Press.

UGS Nezavisnost, 2001. Žene u Srbiji - da li smo žrtve diskriminacije (Women in Serbia - are we victims of discrimination). Beograd

http://www.stat.duke.edu/courses/Spring98/sta110c/qtable.html

http://www.ipu.org/wmn-e/classif.htm 